\title{
American Strategy in The War on Terror: An African Perspective
}

\author{
Innocent Ugochukwu Owutu \\ University of Lagos, Nigeria
}

\begin{abstract}
The terrorist attacks of September 11, 2001, defined the presidency of George W. Bush, who responded by projecting U.S. military power on a global scale. In the months following the attacks, the administration forcefully evicted the Taliban regime and its Al Qaeda sponsors from Afghanistan, while expanding basing rights and military cooperation, for the first time, in Central and South Asia. Indeed, Osama bin Laden is reportedly responsible for a number of these attacks on U.S. government personnel and others during Clinton administration, including the bombings of U.S. embassies in Kenya and Tanzania in 1998 and the attack on the USS Cole in the Yemeni port of Aden in 2000. The study analyzes the various U.S. regimes efforts on the war on terror and its geo- strategic implications especially Africa. In doing this, the study conceptualizes Strategy, Grand Strategy, American National Strategy for Combating Terrorism. It explores the account of the war on terror by U.S. regimes and concludes that Africa's effort in this regard must remain visible to attract American policy makers.
\end{abstract}

Keywords: Strategy, Grand Strategy Terrorism, America, Africa

\section{INTRODUCTION}

The United States has waged this war on terrorism against the backdrop of more traditional geo-political concerns. America has long realized the strategic importance of Asia for international stability and economic growth, but continuing political, economic, and military development poses new and significant challenges to U.S. leadership in the region. The rise of China and India, as well as Russia's struggles to resume a leading global role, are indicative of 'tectonic shifts' [1] in geo-political power and influence in Asia. Additional issues including possible conflict over Kashmir, tension in Taiwan Strait, the maturing nuclear threat from North Korea, and political stability in Central, South and Southeast Asia, all assume new meaning in the light of the ongoing war on terrorism and radical Islamism.

This period is characterized by a very different kind of threat: not new one, by any means, but a threat that has the means to carry out massively destructive acts 'unbridled by the interests, form and structure of a state'. The terrorist threat is a brute use of force, more understandable in a medieval context than in post modern society. Although it does not compare directly to the military might gathered by the two great ideological movements of fascism and communism, its implications are nonetheless potentially momentous. The use of terrorism implies an attempt to 'de-legitimize the concept of sovereignty' and even the structure of the state system itself.[2]

When George W. Bush became the 43rd President of American after a tightly contested election, he presided over a country that, having emerged triumphant from almost 50years of the cold war, hoped to enjoy, a long period peace and security. By this period, the Soviet Union had disappeared, and the Warsaw Pact, which had posed such a formidable military threat to the U.S. and its allies, was no more. 
It is understandable; this state of affairs was judged to be both "propitious and desirable". Although some analyst expressed skepticism about the stability of this new post-cold war order, most viewed this unipolar moment as offering the United States an unprecedented opportunity to create a durable peace that would provide order and stability globally, while permitting its citizens to enjoy the peace dividend that could only be dreamt about during their struggle with the Soviet Union.[3]

The terrorist attacks of September 11, 2001 in Washington DC, New York City and Pennsylvania were acts of war against the United States of America and its allies, and against the very idea of civilized society. President Bush declared that:

No group or nation should mistake America's intentions: We will not rest until terrorist groups of global reach have been found, have been stopped and have been defeated. No cause justifies terrorism. The world must respond and fight this evil that is intent on threatening and destroying our basic freedoms and our way of life, freedom and fear are at war.[4]

This call for the world to respond and fight terrorism by the U.S. falls on the lapse of Africa. Inasmuch as Africa "is not a central concern of U.S. security policy is beyond question when placed within the context of other key U.S foreign policy priorities". In contrast to regions such as South and Central Asia where the activity and resilience of terrorist organizations that harbor strong anti-US sentiment pose a more potent threat to U.S security. The decrease of violent conflict across the African continent further diminishes Africa's status as a global security risk.[5]

The study assesses American war on terror with special focus on George W. Bush and Barrack Obama regimes. Towards this end, it is divided into six sections. The first conceptualizes strategy and grand strategy. The second evaluates American National Strategy for Combating Terrorism, third, looks at the account of George W. Bush in war on terror; four assesses Barrack Obama anti-terror stance, five surveys U.S. anti terror war and the effect on African continent. Finally, the conclusion highlights some consequences of the confrontation with terrorism for America's strategic role in the world.

\section{UNDERSTANDING STRATEGY}

Strategy has several meanings, some narrowly defined, some broadly. Several apply to the nature of strategy, strategic theory or strategic studies. The first set pertains or concerns the use of military force and war between political communities. The word strategy has its origin in the Greek word "strategos", which is normally translated as "general", or the "art of the general".[6]

Following post-Clausewitzian interpretation of the word, strategy is the bridge that relates military power to political purpose. It tells one how to conduct a war, or how to achieve political objectives, using the military instruments. In the Clausewitzian sense, strategy is the use that is made of force and the threat of force for the ends of policy.[7]

Literally, Clausewitz stated that strategy is the use of engagements for the object of the war. Freely translated he tells us that strategy is the use of tacit and explicit threats, as well as of actual battles and campaigns, to advance political purposes. However, strategy may not be (purely) military strategy; instead it may be grand strategy that uses "engagements", meaning all of the relevant instruments of power as threats or in action, for the objectives of statecraft.[8] 
Strategy thus provides the conceptual link between action and effect and between instrument and objective. It is an idea. Strategy is a plan of action designed in order to achieve some end; a purpose together with a system of measures for its accomplishment.[9]

Liddell-Hart suggests that strategy is the art of distributing and applying military means to fulfill the ends of policy.[10] Andre Baufre captured the interactive nature, the dueling character of strategic behaviour, when he states that strategy is the art of the dialectic of two opposing wills using force to resolve their dispute.[11]

A recently posited definition emphasizes the dynamic nature of this process, and of this constant adaptation to shifting conditions and circumstances in a world where chance, uncertainty and ambiguity dominate.[12]

Strategic Studies is the use of policy approach to attain set objectives within target time and at the minimum cost possible. In strategic studies, there is active as well as passive strategy. But about as much as ninety percent of active strategy consists of crisis management, the active form of strategy is more critical to our study. This is because it is directed as designed situation.

It is a policy science and vital in maximizing returns or rewards. It is in this pragmatic sense that strategy is all about planning to excel. Planning therefore, represents a crucial element in strategy. Today, as it were, every business engages in strategic planning. Thus, we can speak correctly of strategic investment, strategic weapons, strategic theatre, strategic thought, legal strategy, football strategy or even market strategy.[13]

Has the end of cold war symbolised the end of strategic studies? Proponents of this line of thought are saying that in the post cold war period, the strategic studies has yielded its way to the security studies due to widespread of security concerns in the world society nowadays.[14] This line of thought was supported with the classification of strategic studies into three stages, arising from the birth of nuclear weapons.

The first stage began in early 1950s, with few theoretical achievements worth noting since it was the time of infancy for the concept formation. The second stage, between 1956 and 1985 became the golden age of strategic studies. This was the period strategic studies was introduced in the universities with academic and practical significance to policy making, and the theories related to nuclear deterrence became core values of strategic studies.

It appears the third stage came up in the late 1980s as the cold war drew to an end. Security concerns played dominant part and possible signs of paradigm shifting occurred. For some, the sign might indicate a weak theory tendency that seemed unable to explain the world appropriately. Indeed, not much progress in theoretical improvement in strategic studies to justify its state-centric academic stand. It would appear that the core values that strategic studies once cherished and built for in the cold war period were called into serious questions.[15]

As the debate rages, among the social, political, economic, environmental and military (grand strategy), a great distinction is discernible. Military strategy is the one that is not peculiar in character to individuals or nations, but one which defines the fate of every man or woman in the nuclear urban world. It is a subset of national or grand strategy, a scientific knowledge 
which studies the conditions and the nature of future wars. Also, the methods for its preparation and conduct, the services of the armed forces and the foundations for their strategic utilization as well as foundation for the material and technical support and leadership of war and the armed forces.[16]

Lastly, strategic thought is not an abstraction; it is the intellectual realm of strategy, a pragmatic science in the mode of thinking of statesmen, military intellectuals, especially political and historian strategists on the concepts, mode, principles, tactics and conventions on the planning and conduct of war. In its pragmatic stance of the conduct of war, it is influenced by prevailing strategic circumstances of the time.

Strategic thought is the province of political scientists, historians and historically oriented military thinkers, and essentially students and practitioners of international relations, diplomacy and strategic studies. For instance, B.H. Liddell-Hart, J.F.C. Fuller, Giubio Douhet, Bayon de Jomini, Carl Marie von Clausewitz, Sun Tzu, Napoleon Bonaparte, Shaka Zulu, Mao Zedong and Niccolo Machiavelli were among the military historian strategists. Jomini and Clausewitz, the first major conceptualisers of military strategy were primarily influenced in their strategic thinking and writing by the Napoleonic wars and early historical experience.[17]

\section{AMERICAN NATIONAL STRATEGY FOR COMBATING TERRORISM}

The United States government is not letting anything lying low in the war against terrorism as she declared that America is at war with a transnational terrorist movement fueled by a radical ideology of hatred, oppression and murder. U.S National Strategy for Combating Terrorism was first publish in February 2003 which recognizes that she is at war and protecting and defending her homeland, the American people, and their livelihood remains her first and most solemn obligation.

Emphasizing further, U.S Strategy also recognizes that the war on Terror is a different kind of war, which from the beginning has been both a battle of arms and a battle of ideas. Not only does she fight her terrorist enemies on the battlefield, she promotes freedom and human dignity as alternatives to the terrorist's perverse vision of oppression and totalitarian rule.

The document further indicated that the paradigm for combating terrorism now involves the application of all elements of her national power and influence. Not only does she employ military power, she uses diplomatic, financial, intelligence and enforcement activities to protect her homeland and extend her defenses, disrupt terrorists operation, and deprive the enemies of what they need to operate and survive.[18]

The 2003 United States Strategy on Terrorism stated that "combating terrorism and securing the U.S. homeland from future attacks are our top priorities". This is in support of National Security Strategy of the country. As its highlight states "we live in an age with tremendous opportunities to foster a world consistent with interests and values embraced by the United States and freedom loving people around the world"

Section 111 on Strategy for Combating Terrorism further supports National Security by "expounding on our need to destroy terrorist organizations, win the "war of ideas", and strengthen America's security at home and abroad". In the same line "National Strategy for Homeland Security focuses on preventing terrorist attacks within the United States". It includes in its distinction that "the National Strategy for Combating Terrorism focuses on identifying and defusing threats before they reach our border".[19] 
To win the War on Terror, America intends to:

- Advance effective democracies as the long-term antidote to the ideology of terrorism.

- Prevent attacks by terrorist networks

- Deny weapons of mass destruction to rogue states and terrorist allies who seek to use them;

- Deny terrorists the support and sanctuary of rogue states

- Deny terrorists control of any nation they would use as a base and launching pad for terror; and

- Lay the foundation and build the institutions and structures we need to carry the fight forward against terror and help ensure our ultimate success.

In less than five years from September 11, 2001, America has successfully acknowledged the following:

- We have deprived al-Qaida of safe haven in Afghanistan

- A multinational coalition joined by the Iraqis are aggressively prosecuting the war against the terrorists in Iraq

- We have significantly degraded the al-Qaida network.

- We have led an unprecedented international campaign to combat in terrorist financing...etc.[20]

So far the study has devoted the last section on the American strategies in the war on terror; it is by no means exhaustive. These are challenges, goals and objectives need more analysis as the account of George W. Bush era would proffer.

\section{GEORGE W. BUSH AND THE WAR ON TERROR}

Some assessment questions here would direct the analysis:

- If someone else had been president of the United States, would he also have invaded Afghanistan and Iraq?

- Was it a good idea for the United States to have invaded the two countries at all?

- To what extent has Bush's War on Terror been successful?

- Has Bush's democratization of the greater Middle East succeeded?

The attacks of 9/11 were far more dramatic and shocking that anything else Osama bin Laden and al-Qaida had done before. It gave rise to some sense that America itself was vulnerable and the fear that more of such attacks on its soil could come up. The Taliban did not adhere to the U.S. ultimatum to turn Bin Laden over hence the invasion that successfully drove the regime from power by the end of 2001.

The truth is that President Bush was in power during the attack and his administration conceptualized the War on Terror and designed its strategy that culminated in the invasion of Afghanistan in 2001 and Iraq in 2003. The government's terror policies had several goals one of which was to prevent another attack on the American homeland. Bush administration was successful in this direction.

The capture and execution of Osama bin Laden by U.S. Naval Seals and destroy al-Qaida ability to attack the U.S. Homeland have been achieved in the regime of President Barack Obama. But the two signature policies of Bush's War on Terror, namely the invasions of Afghanistan and Iraq, have had mixed results. The authoritarian regimes of the Taliban and Saddam Hussein 
had been successfully dethroned. But the U.S. has not succeeded in establishing peace and security in both countries and subsequent withdrawal of substantial of its troop buildup.

Reflecting on the above submissions, the highly ambitious U.S. goal of the democratization of the greater Middle East remained uncertain. According to Mark Katz, "it is clear that President Bush did not achieve his ambitious goal of democratizing the greater Middle East. The United States has fostered democracy in Iraq, but it is extremely fragile and has not succeeded in overcoming bitter ethnic and sectarian divisions" [21]. It was envisioned that U.S government support for democratization in the greater Middle East would lead to peace and prosperity there. Consequently, these countries would not support authoritarian opposition movements such as al-Qaida.

\section{PRESIDENT BARACK OBAMA'S ASSESSMENT OF WAR ON TERROR}

The administration of Barack Obama opposed substantially his predecessor's handling of the War on Terror, particularly in resources expended so far. Also the U.S. led interventions in Iraq and Afghanistan has not prevented the spread of radical Islamist in Iraq and Afghanistan or elsewhere. Bush unilateralism in war on terror had harmed America's relations not only with the Muslim world, but also the western allies. Obama's policy on resumption of office in January 2009 tilted towards implementation of a strategy that was the opposite of the Bush era in several aspects.

President Obama insisted on pursuing a multilateral policy in conjunction with America's allies and partners to improve relations with them. The government was determined to withdraw U.S. forces from Iraq and provide additional resources for the war in Afghanistan and the struggle against al-Qaida. Analysts argue that it would require the various factions to cooperate with one another.

On the democratization of the greater Middle East, Obama made it clear that he is not in that direction. According to him, "governments that protect rights are ultimately more stable, successful and secure". It is not what can or should be imposed upon one nation by another. With the political situation in that region Obama called upon Israel to modify its behaviour toward Palestine. He is well aware that the state of Israeli-Palestinian relations has a strong impact on how successful America manages the war on terror.[22]

How successful has President Obama's changed approach toward the war on terror from his predecessor? He opined:

In the decade since those attacks, we have significantly strengthened our defenses and built a steadfast international coalition. In the past two and a half years, we have eliminated more key al-Qaida leaders in rapid succession than any time since September 11, 2001, including Osama Bin Laden, the only leader that al-Qaida had ever known. We can say with growing confidence that we have put al-Qaida on the path to defeat... we will not rest until that job is done.[23]

In addition, there is the improvement in America's ties with many governments that had opposed the U.S. led intervention in Iraq and had been alienated by the Bush administration's unilateralism. Nevertheless, old problems remained as Iraq and especially Afghanistan have shown that these conflicts are far from over. Neither is likely to end just because the United States leaves. 


\section{U.S.-AFRICA POLICY AND WAR ON TERROR}

Peter Schrader in his work argued that "soon after the Second World War, the basic assumption that influenced U.S. policy toward Africa was that external communist pressure was the root of African conflict", as exemplified by President Truman. During the Kennedy years, the anti-communist consciousness literarily overshadowed any tendency to believe that internal national conditions gave rise to insurgency in African countries.[24]

George Kitato submits that while the historical trajectories between the United States and individual African countries undoubtedly vary, one can construe a clear narrative of how the U.S. has engaged with the region in modern history.

The end of the Cold War, however, eroded the strategic importance of African countries within U.S. foreign policy.[25] Robert L. Ostergard's theatrical in the following comment linked U.S. post WW11 policy contradictions to the present war on terror, thus:

Terrorism is first and foremost a problem of governance, either in response to government policy or as an act of government policy. In this sense, the major contradiction in America's post-world war II foreign policy has been that while the U.S. government has been willing to response to Wilson's liberal vision to make the world safe for democracy, it has done so only as a matter of convenience to Americas national interest. That historical contradiction has now crossed paths with the war on terrorism (Africa affected).[26]

There are some statements made in official quarters during Lyndon Johnson's presidency as issues about Africa "petered out as quickly as it had risen... (Africa is) the last issue considered, the first aid budget cut."[27]

It was the administrations of Richard Nixon and Gerard Ford that took intervention in Africa to a new level but was not sustained by Jimmy Carter as there was a change in policy.[28]

The following passage as Banjo wrote represents the direction of President Carter and Ronald Reagan's Africa policy thrust:

The Carter administration again fought a complicated battle between containment policy and the threat of Soviet expansionism and the need to look at internal roots of crises...within African nations themselves. Reagan characterized the Soviet Union as the "evil empire" which was the primary sources of instability in Africa. [29]

At the time George Bush (Snr) took over from Ronald Reagan, he tried to distance from the Old World Order of East versus West politics, as he was not burdened with the same fears that the Soviet Union would succeed in spreading communism to developing regimes in Africa. As Michael Clough opined, "the turnabout in U.S. priorities was most marked in the Horn of Africa."[30]

To lend credence to the above "turnabout" of U.S. Clinton's policy to African conflict especially Liberia issue:

It is on record that, when the Liberian problem came up, it looked like an internal issue. Majority of the international community saw it that way and no state or the 
United Nations were ready to intervene. United Nations intervention was limited to sending some observers and providing funds for ECOMOG operation in Liberia. ECOWAS rose creditably to the challenges of conflict management and peace keeping in West Africa at a time when the great powers (U.S.) had literally abandoned West Africa, and indeed the continent as a whole...[31]

It was understood, for reasons of international strategy, that Africa's conflicts rank lower than those in Bosnia or the former Soviet Union. "Thus at the point of Clinton's entry into the White House, Africa still ranks lowest on the USA's totem pole of international concerns".[32]

According to J. Peter Pham, President George W. Bush "took the shock of the 9/11 attacks to shift the focus of American policy makers and analysts back to Africa in a concerted manner as U.S. geopolitical vision was reassessed in the light of what became known as the 'global war on terrorism'."[33]

President Barack Obama provided some insights into the reality of dealing with Africa policy as one that fits into his primary campaign message 'change' or one that is closer to the shifts of policy. According to Laura White, in early 2010, in Ghana, "President Obama gave an address emphasizing that he viewed good governance as a key to the success of African states, and that this was something that African leaders need to take responsibility for....also insisted that U.S. security interests are at stake in Africa." [34]

The shift is not without its ironies considering the long history of U.S. conflict with terrorists in Africa. Supporting the above, it was understood that the post 9/11 US thinking has metamorphosed into 'if you are not for me, then you are against me'. Therefore, political neutrality or non-alignment on the war on terror suddenly becomes expensive positioning for African States. It was in keeping with the above accounts that the Bush administration announced the US Africa command (AFRICOM) which assumed responsibility for US security relations with 42 out of Africa 53 countries.[35]

President Barack Obama's election as the first African American was accompanied by extraordinarily high expectations for US policy towards Africa. His personal knowledge of and interest in Africa, multilateralism world view generated optimism in conducting relations with African nations. At least, his visit to Ghana, where he made the famous statements, his nominations of several seasoned diplomats having knowledge about Africa, provided earlier indications that there was light in the horizon about Africa.[36]

One of the driving questions of this section is whether Obama's election precipitated any kind of a qualitative shift in the way that the US approaches African affairs. Some African advocates do conclude that Africa is ignored by the United States particularly their policy makers. This is different from others who believed that US-Africa relations have been characterized in the main by indifference and neglect, punctuated by flurries of interest and action.

Would Obama presidency give Africa something to cheer? A popular adage says action speaks more than words as President Obama publicly noted that "our security interests will sometimes require that we work with regimes with which we have fundamental disagreements". Moreover, Obama's policies remain situated within the broader approaches to energy and security which governed U.S. foreign policy for some time and which his administration has not significantly altered. It was for this reason that his heritage and familiarity with issues relevant to the continent are not likely to change the pattern of his polices than the structural relationships that exist between the U.S. and Africa. 


\section{CONCLUSION}

The article has attempted an overview of American strategy in the war on terror and the African perspective toward the success of this fight. U.S. strategy for combating the menace have been laid bay and discussed exhaustively. The two main administrations of George W. Bush and Barack Obama in the eye of the storm have been assessed. Africa's efforts towards war on terror have been put on the table leaving some areas for further research.

The terrorist attacks of September 11, 2001, defined the presidency of George W. Bush and Barack Obama, who responded by projecting U.S. military power on a global scale. The efforts led to the forceful eviction of the Taliban regime in Afghanistan, defeated Saddam Hussein's army in Iraq, hounded and killed Osama Bin Laden and some al-Qaida leaders.

U.S. Strategies for Combating Terrorism, beyond the challenges posed by al-Qaida and other radical Islamist terror groups, has fought relentlessly additional threats that emerged in the post September 11 world vis fallout from weak and failed states, the global effects of political instability in the greater Middle East and Asia, risks posed by the proliferation of weapons of mass destruction and their potential nexus with terrorist groups.

Africa's efforts to the war on terror has not waned, yet whether U.S. shift to a more critical tone will translate into a significant change to the substance of U.S. Africa policy remains to be seen. It should be understood that the strategic interests and importance of Africa to U.S. is not immediately apparent or self evident in contrast to regions such as South and Central Asia, which harbour strong anti-U.S sentiment pose a more potent threat to her security. Contrary to high expectations within Africa that the Obama presidency would herald a new age of U.S Africa relations in war on terror, the reality thus far seems to suggest continuity rather than change.

\section{References}

1. Richard J. Ellings, "Foreword" in Ashley J. Tellis, "Assessing America's war on Terror: Confronting Insurgency, Cementing Primary”, NBR: The National Bureau of Asian Research, Vol. 15 No 4, 2004

2. Audrey Kurth Cronin, "Rethinking Sovereignty: American Strategy in the Age of Terrorism" Survival: The International Institute for Strategic Studies, Vol. 44, No 2 Summer 2002, pp 119 - 39

3. Ashley J. Tellis, “Assessing America's war on Terror" P. 6

4. National Strategy for combating Terrorism, February 2003, P. 1

5. George Katito, “Continuity, Little Change?: U.S Africa Policy under Obama Administration”, South Africa Institute of International Affairs, OASIS 2009 No. 14, pp. 145 - 157

6. J.M. Malik, "The Evolution of Strategic Thought", in Graig Snyder (ed), Contemporary Security and Strategy, Macmillan (London, 1999), p.13; see also: Frans Osinga, "Science, Strategy and War: The strategic Theory of John Boyd" (Amsterdam, Eburon Academic Publishers, 2005) p.14; O.A. Eke, Strategic Studies Logical Focus in the 21st Century (Abakaliki, Willyrose and Appleseed Publishing Coy, 2007), p.15.

7. C. Gray, Modern Strategy, (Oxford, University Press, 1999), p.52: see also, H.R. Yarger, "Strategic theory for the 21st century: The little book on Big Strategy. (U.S. Government, 2006) pp.1-3; J.R. Cerami and J.F Holcomb, Jr. “U.S. Army War College: Guide to Strategy, (U.S. Government, 2001) pp.11-13: W.H. Chen, "Paradigm Shifts: Is Strategic Studies still relevant to the world today" (China Graduate School of International Affairs, Ming Chuan University, n.d) pp. 179-186.

8. Carl von Clausewitz, On War, trans. Michael Howard and Peter Paret (Princeton, NJ, 1976) p.128

9. J.C Wylie J.C. Wylie, Military Strategy: A General Theory of Power Control, (Rutgers University Press, New Brunswick, NJ (n.d), p.13. 
10. B.H. Liddell Hart, Strategy: The Indirect Approach, (London 1967) p.335.

11. Beaufre, An Introduction to Strategy, (London, 1963).

12. W. Murray and M. Grimley, "Introduction: On Strategy" in Murray, MacGregor Knox and Alvin Bernstein (eds), The Making of Strategy: Rulers, States, and War (Cambridge, 1994) p.1

13. O.A. Eke, Strategic Studies

14. W.H. Chen, Paradigm Shift

15. W.H. Chen p.182

16. 0.A. Eke p.16

17. O.A. Eke pp.22-23

18. National Strategy for Combating Terrorism, September 2006, P.1

19. National Strategy for combating Terrorism, February 2003 P. 2

20. National strategy, 2006, pp $2-3$

21. Mark N. Katz, "Assessing the Bush Strategy for Winning the War on Terror”, War on Terror in Perspective, Middle East Policy Council, 2010. www.marknkatz.com. Accessed 20th April, 2015

22. Mark N. Katz, "Assessing the Obama Strategy toward the "War on Terror", War on Terror in Perspective, Middle East Policy Council, 2011 Accessed 20th April, 2015.

23. Barack Obama, "Presidential Address on War on Terror", The White House, Washington, June 28, 2011.

24. Peter Schrader, United States Foreign Policy Toward Africa: Increamentalism, Crisis and Change, Cambridge. 1994 pp.33-34.

25. George Katito, “Continuity, Little Change? pp. 146-147.

26. Robert L. Ostergard Jr., “The Failure of America's Post-cold War Foreign Policy. p. 47. Accessed 20 April, 2015

27. Michael Clough, "Free at last? U.S. Policy toward Africa and the end of the Cold War", New York: Council on Foreign Relations Press, 1992:18.

28. Adewale Banjo, "US Development Diplomacy in Africa: From Bill Clinton to George W. Bush”, African Journal of Political Science and International Relations, 4 (4), p.141, 2010

29. Ibid

30. Michael Cough, "Free at Last? p.12

31. Innocent U. Owutu, “Peace, Conflict and Security: Managing the Tripartite African 'Curse' of the 21st century", in Nigeria Forum: A Journal of opinion on world affairs, Lagos: NIIA, 2011, V.32, 11 and 12, pp. 396-397.

32. Adewale Banjo, p.143.

33. J.P. Pham. "Next front", p.41

34. Adewale Banjo p. 147

35. George Katito p.153

36. Rebecca Burns, par. 1 